\title{
Greening the economy or economizing the green project? When environmental concerns are turned into a means to save the market
}

\author{
Anneleen Kenis ${ }^{\mathrm{a}}$ and Matthias Lievens ${ }^{\mathrm{b}}$

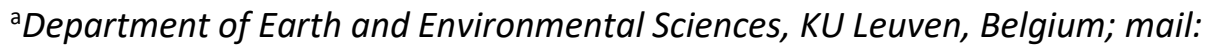 \\ anneleen.kenis@ees.kuleuven.be \\ ${ }^{\mathrm{b}}$ Leuven Centre for Global Governance Studies, KU Leuven, Belgium; mail: $\underline{\text { matthiaslievens@hotmail.com }}$
}

This is the accepted version of an article published in 'Review of Radical Political Economics'. Check the following website for the final, published version:

https://journals.sagepub.com/doi/abs/10.1177/0486613415591803?journalCode=rrpa

To cite this article:_Kenis A., Lievens M. (2016). Greening the economy or economizing the green project? When environmental concerns are turned into a means to save the market. Review of Radical Political Economics, 48 (2), 217-234. DOI: 10.1177/0486613415591803

\begin{abstract}
The 'Green Economy' is fast becoming the new alpha and omega for many policy makers, corporations, political actors and NGO's who want to tackle both the environmental and economic crisis at once. Or would it be better to speak about 'green capitalism'? Going green is not only important in the fight against environmental destruction, it also makes a country "stronger, healthier, safer, more innovative, competitive and respected", argues Thomas Friedman, the well-known New York Times columnist. "Is there anything that is more patriotic, capitalist and geostrategic than this?" Indeed, the rationale underlying the nascent project of the Green Economy is that if the market could become the instrument for tackling the environmental crisis, the fight against this crisis could be the royal road to solving the problems of the market. Focusing in particular on the Green Economy's impact on climate change, this paper analyses the Green Economy as a hegemonic project that tries to retranslate environmental concerns into a new jargon, and to turn environmental conflict into a new motor for economic development.
\end{abstract}

Keywords: Green Economy; green growth; climate change; post-politics; climate justice; hegemony. 


\section{Introduction}

"I believe that the transition to a green economy is good for our economy and good for all of us, and I have invested in it", Al Gore famously stated in a discussion with a member of the US Congress in 2009. Especially in environmentally conscious circles within international institutions, global lobby firms and thinktanks, the 'Green Economy' has rapidly become the new big thing. During the last years, we witnessed a proliferation of initiatives in this field, including Green Economy magazines, a Green Economy Coalition composed of companies and NGO's, and a plethora of conferences, academic papers and reports.

International institutions have played a key role in advancing Green Economy thinking. In 2010 the OECD launched its Interim Report of the Green Growth Strategy, and in 2011, the European Union published a Roadmap for moving to a Low-Carbon Economy in 2050. Of crucial importance, however, was UNEP's 2011 Green Economy Report, a volume of more than 600 pages, which, according to its own words, aims at developing "pathways to sustainable development and poverty eradication". Especially since the Rio+20 United Nations Summit on Sustainable Development, the notion of the 'Green Economy' has gained centre stage in international debates and policies on sustainability.

Even though the project for a Green Economy is in a lingering crisis since the successive failures of the international climate summits, the fast rise and predominance of the discourse on the Green Economy is yet of huge significance. It transforms the terrain of the discussion on environmental questions, and opens the door for a relatively new set of actors to become the standard-bearers of the fight against the ecological crisis (such as corporations and banks), and for a new (market-based) paradigm of policy-making. Admittedly, this shift in green thinking has a long pre-history. The attempt to frame environmental questions in liberal, economic terms has been a constant since 30 years or so (Bernier 2012). As is well-known, a multiplicity of meanings has been attributed to the famous notion of 'sustainable development' which since the 1987 Brundtland report has structured the international environmental debates. The Green Economy appears to be the outgrowth of a specific interpretation of this notion: one which especially stresses the capacity of the market to deliver sustainability, and to reconcile economic, environmental and social goals.

In this paper, we analyse the rise of the Green Economy discourse as a hegemonic shift with potentially broad ecological, social, ideological and (geo-)political implications. Methodologically, the paper draws on different sources. Inspired by critical environmental sociology and ecological marxism (including authors such as John Bellamy Foster and Paul Burkett), it draws on Antonio Negri, Michael Hardt and Antonio Gramsci's analyses of how capitalism reacts to oppositional movements and attempts to turn forms of struggle, in this case environmental struggles, into a motor for capital accumulation and economic development. These analyses are further enriched with the help of recent political-theoretical approaches to the problem of post-politics or depoliticization. Post-politics results from the process of reintegration and recuperation of environmental conflicts within capitalism: this recuperation requires a translation of environmental questions from conflict matters into objects of all-round cooperation.

The paper explores the limits of the Green Economy project particularly from the point of view of climate change, which is undoubtedly one of the major ecological crises we face today, although a focus on other ecological crises would probably lead to similar conclusions. The paper proceeds in three steps. First, we shortly describe the basic ingredients of the Green Economy project. Subsequently, we analyse 
the hegemonic implications of the rise of Green Economy discourse. We argue that greening the economy constitutes an example par excellence of passive revolution, whereby an attempt is made to turn the preexisting conflict matter into the source of renewed capital accumulation. The crucial question, of course, concerns the extent to which capitalism will succeed in turning conflict into consensus around a new, green mode of accumulation and to what extent this project for green accumulation will be successful at all. As Marx (1973) has argued, capitalism has a strong capacity to turn obstacles into barriers and thus into new opportunities. However, some obstacles will be very difficult to surmount, as we will argue. Finally, looking for pathways beyond the Green Economy, the paper ends with a discussion of the conflicts that will inevitably unfold in the framework of the Green Economy experiment, and which can provide the basis for a repoliticization of the climate question.

\section{Green Economy: basic ingredients}

The Green Economy encompasses a whole spectrum of policy agenda's, ranging from Thomas Friedman's 'Green Revolution', via UNEP's models and scenario's, to the more progressive variant of the Green New Deal first developed by the British Green New Deal Group. On top of this, there is the discussion on 'Green Growth', advocated in particular by the World Bank and the OECD. Within the academic world, the Green Economy is becoming a topic of interest as such, but many other approaches have affinities with it as well, such as ecological modernization or transition management. The notion of the Green Economy increasingly functions as a catch-all for this patchwork of perspectives and approaches.

There exists a range of variation and nuances, therefore. Many of these approaches slightly differ on a number of points: the extent to which they advocate government regulation and investment, the role they attribute to financial markets and techniques, the instruments used to create and correct markets, etcetera. At the same time, however, a number of red threads recur. We distinguish four ingredients which most variants of the Green Economy share. The first is to realize a transition towards sustainability via the market. This can be done by correcting existing markets, or by creating completely new, artificial markets. Examples of the first approach include subsidies and taxes which are supposed to make sure that products are 'correctly priced'. Forms of labelling or certification systems also function as soft forms to correct or steer the market. In this way, it is supposed consumers and companies will be induced to make environmental-friendly choices on the market. "Much of green growth is about good growth policies", the World Bank argues, "addressing market failures and 'getting the price right' by introducing environmental taxation, pricing environmental externalities (such as carbon pricing), creating tradable property rights, and reducing inappropriate subsidies" (World Bank 2012, 12).

Next to this, a range of experiments is undertaken with the creation of new, artificial markets. The most obvious example is the carbon market. The latter increasingly functions as a precedent for the implementation of similar markets in other fields. For example, UNEP (2011) advocates Payments for Ecosystem Services (PES), trade in pollution permits or in access rights to water, wetland banking schemes etcetera. Establishing such new markets evidently presupposes introducing private property principles and giving a price to nature. If the economy is supposed to become bio-based, for example, the whole question arises as to who owns the biomass. Unsurprisingly, attempts to privately appropriate this biomass are the result (ETC-Group 2011). 
The second ingredient of the Green Economy follows from this focus on the market. When markets are corrected from a 'green' perspective and competition is intense, new technologies will arise which will get us out of the current crisis. "Give me abundant, clean, reliable, and cheap electrons, and I will give you a world that can continue to grow without triggering unmanageable climate change", Thomas Friedman $(2008,186-187)$ writes. We therefore need a market that can quickly commercialize promising ideas developed by companies or universities, he argues, as this will stimulate innovation. Technological and managerial innovation is an absolutely crucial ingredient for the Green Economy, as is stressed time and again in well-known reports of international institutions (World Bank 2012, UNEP 2011, OECD 2011). An example of the typical mix of beliefs in markets, economic growth and technological innovations is the Breakthrough Institute, whose leading figures advocate nuclear energy as a 'safe' and 'cheap' solution to climate change (e.g. Shellenberger \& Nordhaus 2013). Similarly, academic currents such as postenvironmentalism (Buck 2012) or ecological modernization (Mol and Spaargaren 2000, Spaargaren and Mol 1992) strongly focus on the interplay between markets and technology.

A third recurring ingredient is sustainable entrepreneurship or corporate social responsibility, next to other voluntary engagements of the private sector. Market actors, once they become 'conscious' or 'responsible', have all the power needed to change productive practices, it is assumed. Numerous companies seem to have discovered green ideas over the last decade (but whether that leads to actual changes in practice is of course an entirely different matter (Dale 2008)): from BP changing its name into 'Beyond Petroleum', to Coca-Cola offering 'a bottle of hope' during the Copenhagen climate summit in 2009. Increasing cooperation between NGO's and companies is also typical for this trend. WWF, for instance, has partnerships with companies such as Nokia, HP, Volvo, Ikea, Sony and Monsanto. The underlying idea is that as companies are becoming increasingly environmentally 'conscious', they can be changed from the inside, by helping them to put their practices, products and services on a better ecological footing.

The fourth ingredient is closely related to this: by choosing environmentally friendly products, consumers are supposed to be able to encourage companies to 'green' their practices. Sustainable consumption should therefore be actively promoted (e.g. UNEP 2011; Worldwatch Institute 2010) and is sometimes even seen as the 'holy grail' of the transition towards sustainability (Jackson 2005, 121; see also Kenis and Mathijs, 2012). Significantly, Al Gore, a staunch advocate of green economy thinking, closes his film An Inconvenient Truth with a list of sustainable choices individuals can make as consumers: buy energy efficient appliances, light bulbs, a new thermostat, a hybrid car, etcetera. Similarly, the official website of COP19 stated: "Every one of us may contribute to stopping or, at least, limiting climate change" ${ }^{1}{ }^{1}$ The way this proposal is made concrete speaks for itself: "Reduce the use of electric energy (...) by choosing energy-saving equipment (marked with $A, A+, A++$ symbols) with thermostats and time switches. (...) Save water - by remembering to close the tap (also when brushing your teeth) or by installing a special spout" etcetera. As a conclusion, the website aptly states: "Become a conscious consumer", this "will not only decrease the amount of waste, but also the amount of energy needed to produce what we consume."

Overseeing these different ingredients, a number of elements which are fundamentally at the basis of the ecological crisis, at least according to critical environmental sociologists (e.g. Burkett 1999;

\footnotetext{
${ }^{1}$ http://www.cop19.gov.pl/about-climate-change
} 
Foster, Clark and York 2010; Klitgaard 2013), are conspicuously absent. The fundamental social (class) relations of capitalism, based on the commodification of nature and labor, are strengthened rather than questioned in the Green Economy project. Rather than fundamentally transforming existing relations of production, limiting growth, rolling back global trade and fighting speculative mechanisms on financial markets, the Green Economy reinforces these elements, assuming it is possible to mobilise them in view of a sustainability transition.

\section{Green Economy as a hegemonic project}

In his best-seller Hot, Flat, and Crowded: Why We Need a Green Revolution-And How It Can Renew America, Thomas Friedman pointedly summarizes the philosophy of the Green Economy. "There is only one thing bigger than Mother Nature and that is Father Profit", he states (Friedman 2008, 244). That is why we should mobilize Father Profit, he suggests, in order to save Mother Nature. Friedman is undoubtedly one of the most intelligent and influential advocates of the 'Green Economy', although he himself prefers to speak about the 'Green Revolution' or about 'Code Green'. The idea is simple: if we want to make the transition to a green future, we should mobilize market mechanisms and the innovative nature of capitalism.

But for Friedman, more is at stake than fighting environmental destruction. The Green Economy is not merely the solution for climate change and other environmental problems. It is also the exquisite chance for the US to again become hegemonic and regain its moral leadership in the world, which has been seriously undermined since the subprime crisis and the failures in Iraq and Afghanistan. Greening the economy, for Friedman, creates a possibility for the US to become less dependent on oil from autocratic countries which finance religious extremism, and on making war for safeguarding oil provision. "Making America the world's greenest country is not a selfless act of charity or naive moral indulgence. It is now a core national security and economic interest", he argues (Friedman 2008, 23). "Everything America (or any country) can do to go green today will make it stronger, healthier, more secure, more innovative, more competitive, and more respected. What could be more patriotic, capitalistic, and geostrategic than that?" (Friedman 2008, 173). And what is almost as important: the Green Economy also opens a vast terrain for profit-making activity. Friedman quotes Lois Quam, managing director of alternative investments at Piper Jaffray, an investment company, saying: "The green economy is poised

to be the mother of all markets, the economic investment opportunity of a lifetime, because it has become so fundamental. (...) The challenge of global warming presents us all with the greatest opportunity for return on investment and growth that any of us will ever see. To find any equivalent economic transformation, you have to go back to the Industrial Revolution" (Friedman 2008, 172). In other words: the Green Economy is not merely about saving the planet, but also, or even primarily, about saving capitalism. In any case, this is how the project is presented - whether it will fulfill its promises is an entirely different matter.

In a critical analysis of what they call 'green capitalism', Mueller and Passadakis (2010) make a similar observation. Capitalism is confronted with a triple crisis, they argue. First, there is the legitimation crisis, most clearly manifested in the ongoing protests against international institutions such as the WTO, IMF, World Bank and others. Second, we face an accumulation crisis, a deep crisis that has profoundly 
shaken the global economy. Third, there is the biocrisis, including climate change, biodiversity loss, desertification, peak oil etcetera. In a more systematic way than Friedman, Mueller and Passadakis point to what is at stake in the project for a Green Economy. If it becomes possible to tackle the ecological crisis with market mechanisms, this might make it possible to not only do something about the environment, but especially to set global capitalism on a new footing. Paradoxically, climate change (and the other global environmental crises) appears to provide capitalism with a chance to overcome the impasse it is in. Indeed, greening the economy might become the royal road to saving capitalism, as it in actual facts entails the commodification and marketization of the green project.

This is a recurrent argument in favor of the Green Economy. Protecting the environment would not merely be compatible with economic growth. Environmental policies are also supposed to trigger a new phase of growth (Jacobs 2013). As the World Bank president Jim Yong Kim states: "We have to find climate-friendly ways of encouraging economic growth. (...) The good news is we think they exist." The British economist Nicholas Stern confirms: "It's a very exciting growth story" (Stewart and Elliott 2013).

The argument is clever: the Green Economy appears as the royal road to exit the current triple crisis, and especially the economic one. Fundamentally, the latter is a crisis of overaccumulation, a number of authors have argued (e.g. Callinicos 2010; Foster and Magdoff 2009; Joshua 2009). The best way to overcome such crises is by creating new markets. But the potential to do that is limited since neoliberal globalization has capitalized developed countries, the former East Block has entirely been marketized, and many formerly public sectors have been privatized. The ecological crisis seems to provide an alternative way out: in the eyes of 'intelligent investors', it opens perspectives for the creation of new markets, some of which could become huge in size. Evidently, markets in green products, such as windmills, solar panels or organic food are booming. But even more promising prospects are lurking at the horizon: the creation of entirely new and artificial markets, of which emissions trading provides a prime example. In 2010, it was forecasted that a serious successor of the Kyoto Protocol, including the US, could spark a market of about 4500 billion dollar within ten year (Energy Business Reports 2012). Adding the market for derivatives, this figure might be even multiplied several times (Bond 2012).

The stakes are high: if the market can become the instrument for tackling climate change (and other environmental crises), the struggle against climate change could become the royal road for solving the problems of the market - at least so it is thought. Evidently, certain sectors will see their market shares reduced, but elsewhere, huge opportunities can be created. "The investment opportunities presented by the transition to a Green Economy are unparalleled. The low carbon, resource efficient transformation of cities, industries, energy and transport systems, as well as the provision of finance and capital for those at the Base of the Pyramid, presents our capital markets and the global financial services sector with unprecedented challenges and opportunities", David Runnalls writes (2011).

\section{Passive revolution}

A peculiar means-ends reversal seems to be at work in the Green Economy project: instead of being a goal in itself, climate stabilization becomes a starting point or a means for assuring renewed growth and economic and political hegemony. Evidently, this can only succeed if what was previously a conflict matter ("ecology against capitalism", as in the title of one of John Bellamy Foster's books (2002)) is re-translated 
into a source for the modernization of capitalism. In other words, this means-ends reversal is made possible by a complex and strange process: what was previously a critique and a source of opposition against the economic system, is turned into a source of capitalist renewal. It is of course not the first time that such a dynamic can be observed.

A number of sociologists, and especially autonomist marxists such as Mario Tronti (1977) and Antonio Negri and Michael Hardt (2000), have shown that many developments which lead to a renewal of capitalism cannot be understood unless one pays attention to forms of resistance and opposition against capitalism. What is more, resistance and opposition are often the motor forces of important transformations within capitalism. Boltanski and Chiapello (2007) have shown for example how certain critiques against capitalist society, as they were formulated by the May '68 movement, have been intelligently integrated in the system, e.g. through new human resources management discourses. Negri and Hardt (2003) have made a similar argument, although for them, this recuperation of resistance has a broader bearing: it can even become the motor force behind new forms of capital accumulation. They famously showed how Keynesianism involved a transformation of capitalism in which the opposition of labor to capital was internalized in a new dynamic of capital accumulation. The workers' wage demands were turned into the motor force behind a new capitalist configuration relying on mass production for mass consumption. This laid the basis for what were probably the most dynamic decades western capitalism has ever known.

The contemporary rise of the project of the Green Economy might be another example of such a dynamic. This project constitutes an attempt by international institutions, governments, companies, think tanks and banks to intelligently answer the ecological critique of market society. The content of this critique is translated into a different language, and the energies mobilized by environmental movements are drawn towards the creation of new possibilities for capital accumulation.

What is behind this dynamic is a singular logic of the invention of a new type of capitalism: what used to be a matter of deep conflict and antagonism is turned into a new regime of accumulation. A wellknown quote by the British utopian socialist William Morris (1886), which Negri and Hardt (2000) use in the beginning of their book Empire, captures what is at stake rather well: "Men fight and lose the battle, and the thing that they fought for comes about in spite of their defeat, and then it turns out not to be what they meant, and other men have to fight for what they meant under another name". The students of May '68, the workers of the decades preceding the advent of Keynesianism, and the environmental movement all probably had different goals in the beginning. In a sense, to follow William Morris, they were defeated, but their protest nevertheless sparked important changes, through which what they advocated came into being in a completely different form than originally intended.

Negri and Hardt come close to Antonio Gramsci's analysis of how capitalism reinvents itself and re-establishes its hegemony after a wave of struggles against it. Gramsci (1998) spoke about "passive revolution" or "revolution-restauration", which is a process through which, as an answer to previous opposition and crisis, an attempt is made to reconstruct the hegemony of capital and the capitalist state by making changes which can be quite fundamental even though they do not touch the core parameters of capitalism as such. In this context, it is very significant that advocates of green capitalism such as Thomas Friedman speak about a "green revolution": they acknowledge the profundity of the changes needed, while they fundamentally remain within a market framework. 
Both Gramsci and Negri and Hardt have stressed that such changes within capitalism especially also affect the composition of social and political forces that existed previously. In the autonomist terms Negri and Hardt use, they generate a process of 'de-' and 'recomposition' of the social forces involved. Gramsci $(1998,58)$ especially also paid attention to how, through a passive revolution, the leadership of the opponent force (the workers movement) could become integrated within the new capitalist power block that was being created (he called this phenomenon "transformism"). Something similar is at stake in the current attempt to realize a Green Economy, whereby a number of NGO's are joining forces with companies and banks participating in Green Economy projects.

\section{Hegemony and recomposition}

The speed with which the discourse of the Green Economy has gained centre stage is remarkable: until five years ago, this was still a marginal notion, and in so far as it was used by NGO's or political forces, the term was often not well-defined. Now it increasingly functions as a nodal signifier around which a whole set of actors, demands and ideas cluster. In this sense, it is the hallmark of a genuine hegemonic project (Laclau and Mouffe 2001). Indeed, the Green Economy discourse, in all its variants, seems to be succeeding in hegemonizing the environmental field, to the extent that it also becomes the focal point of many critical and oppositional forces. While critical environmental movements during the Copenhagen summit still primarily targeted what they called 'false solutions' for climate change (TNI 2008), increasingly they are turning against the Green Economy itself (Mueller and Bullard 2011).

This means the Green Economy discourse is generating a recomposition of the ecological field. This recomposition is actively pursued by Green Economy advocates, who try to gather as many forces as possible behind this market version of environmentalism. Time and again, it is stressed that the Green Economy will create jobs (E.g. UNEP 2008), and that it ought to engage the lowest social classes. In the words of Friedman (2008, 336): "Code Green has to prove that it can offer something to the very lowest rungs of the economic ladder, not just to upper-middle-class people. If all Americans can't see outgreening as a strategy that could improve their lives, it will never generate the momentum and scale that it needs to succeed". In many versions of the Green Economy, NGO's, civil society organizations and even labor unions are invited to support the project, and become actively involved, in a sphere of cooperation. A broad but loose transnational alliance of actors is thus emerging, ranging from international institutions to global think tanks, from international NGO's to sectors of both green and liberal parties, from certain industries and even financial institutions to academics.

Strikingly, this is not an alliance against fossil fuel capitalists, banks or speculators: on the contrary, it is a coalition that aims to include these as well, with the hope to change them 'from the inside'. The 2013 Warsaw climate summit was a case in point. "By being creative, the world can reduce greenhouse gas emissions while creating jobs, promoting economic growth and ensuring better living standards. Where there is a will, there is a way!", Marcin Korolec, the summit's chair, stated optimistically. ${ }^{2}$ And he strongly defended the inclusion of companies such as ArcelorMittal, Emirates and

\footnotetext{
${ }^{2}$ http://www.cop19.gov.pl/the-president-of-cop19-cmp9
} 
BWM as partners of the summit, as if that would boost the success of the summit, or make these companies greener.

Through such moves, an open hegemonic struggle against pre-existing, fossil fuel capitalism is usually avoided in favor of a broad-based and inclusive transition process in which key players of actually existing capitalism (energy companies, car manufacturers, banks and other financial actors) supposedly have a key role to play. In other words, a broad, inclusive and "expansive hegemony" is pursued by the Green Economy project (Mouffe 1979).

Evidently, there are some approaches that do recognize the inevitability of agonism. The Green New Deal Report, which some call the "left wing" of the project for a Green Economy (Mueller and Bullard 2011, 2), for example pleads for "a new political alliance: an alliance between the labor movement and the green movement, between those engaged in manufacturing and the public sector, between civil society and academia, industry, agriculture and those working productively in the service industries" (Green New Deal Group 2008, 6). Significantly, the report suggests this alliance is directed against at least one opponent: "the dominance of the finance sector in the economy". Most often, however, this is not the case.

In his book The Green Collar Economy: How One Solution Can Fix Our Two Biggest Problems, Van Jones (2008) advocates the building of an alliance composed of the organized labor movement, social justice activists, environmental groups, students and faith organizations. Bringing Jones' ideas into a Gramscian framework, Boone Shear $(2010,204)$ call this a "new historical bloc". Shear appears to be very optimistic about the possibility for the left to appropriate the Green Economy discourse. Perhaps his statement that "political possibilities for the Green Economy (...) are not constrained and produced through an already hegemonized field" (Shear 2010, 205) has already become outdated, given the strong hegemonization of the Green Economy discourse by international institutions, market-oriented think tanks and lobby groups the last couple of years. Indeed, as the environmental field is recomposed, adversaries of the market ideology which is typical for the Green Economy, also have to reinvent and reorganize themselves. This has led to the growth of an increasingly visible movement for 'climate justice', a notion which serves as an alternative nodal point juxtaposed to the Green Economy (Bond 2012; Mueller and Bullard 2011; see also Kenis and Mathijs 2014a).

The climate justice movement argues that the Green Economy project faces a number of obstacles which might make it impossible to reduce greenhouse gas emissions fast enough in order to stabilize the climate. Furthermore, the movement argues that greening the economy through market mechanisms threatens to shift the cost of this transition towards lower social classes both in the Global North and in the Global South.

\section{Obstacles and barriers}

The question which obstacles the Green Economy faces is not an easy one. In a certain way, capitalism thrives off the confrontation with obstacles. "(A)s representative of the general form of wealth - money -," Marx $(1973,334)$ wrote in the Grundrisse, "capital is the endless and limitless drive to go beyond its limiting barrier. Every boundary is and has to be a barrier for it. Else it would cease to be capital - money as self-reproductive". Capitalism, Marx suggests in this passage, has an enormous capacity to turn each boundary into a barrier that can be transcended. It is this dynamism which distinguishes it from previous 
forms of society. From the perspective of capital, obstacles are no hard limits, but open the door for more (Kovel 2007). Each obstacle is the starting point for the creation of new markets, new commodities, and new profit opportunities. As Paul Burkett (2006) has shown, even environmental degradation is seen as an opportunity for new forms of capital accumulation. If local resources are exhausted, one can import others via the world market. If there is a problem with excessive waste, the market will quasispontaneously produce a waste industry, which will burn, export, recycle or bury it. New illnesses as a result of environmental pollution provide the pharmaceutical sector with new opportunities. If people suffer from depressions and burn-outs, the wellness industry will turn a profit from it. If too much $\mathrm{CO}_{2}$ is emitted, a new market is created for trading emissions. Capitalism always appears to be able to find ways out of its crisis, on the condition that these can be sold.

Something similar is at stake in the current project for the Green Economy. Rather than seeing the ecological crisis as a limit for capital accumulation, the crisis is turned into a new opportunity for further accumulation. At the same time, however, the capitalist solution for one crisis threatens to recreate new social and ecological crises on ever higher and complex scales. As John Bellamy Foster, Brett Clark and Richard York (2010) show, Marx already observed that when the local soil was depleted as a result of the ruptured social-natural metabolism in nineteenth century British agriculture, the predominant answer was simply to import soil from elsewhere. However, the massive importation of guano and other nutrients from Latin American countries threatened to disrupt the metabolism on a global scale. To take another example: the market solution for climate change (e.g. emissions trading) threatens to reinforce other ecological crises, such as biodiversity loss, as plantations with fast-growing trees are set up in order to 'offset' carbon emissions.

When the ecological crisis becomes the starting point for the creation of new market opportunities, the almost inevitable result is that the market logic is introduced on terrains which were previously untainted by it, and that even nature itself becomes capitalized (Smith 2006). It is no longer a mere resource or a place to dump waste, but the very product of capitalism: capital produces nature (e.g. forest plantations) in order to capture $\mathrm{CO}_{2}$, for example.

Consequently, the ecological boundaries which capitalism is increasingly confronted with, are not always as strict. Capitalism is capable of playing with these boundaries, shifting them or postponing their effects. It buries waste in the ground or attempts to store $\mathrm{CO}_{2}$ deep in the soil via the controversial technology of 'carbon capture and storage'. The latter technique may merely delay rather than fundamentally solve global warming, and also introduces new risks, including leakages of $\mathrm{CO}_{2}$ from underground reservoirs (Marshall 2010).

This does not mean that limits are inexistent. Researchers of the Stockholm Resilience Centre have analyzed nine "planetary boundaries within which we expect that humanity can operate safely", each of which is threatened by major environmental crises (Rockström et al. 2009). Yet, from the viewpoint of capitalism, it is more 'rational' to develop new and often risky technologies (e.g. geo-engineering) to avoid the worst effects of climate change than to tackle the root causes (burning fossil fuels in an economy based on unlimited growth), and it is more attractive to set up mechanisms to 'compensate' for or 'offset' emissions rather than reducing them. The result is a worsening environmental crisis, but this does not immediately and necessarily endanger capitalism itself. The kind of nature capitalism needs is of a poorer kind than that which is needed for qualitative human life (Burkett 2006). 
Yet, the central question is of course whether these attempts to 'green' capitalism will be sufficient to really ward off the damaging consequences of environmental crises, more in particular climate change. Furthermore, it is important to underscore that this transformation of boundaries into barriers, and the opening of new fields of capital accumulation are not automatisms. They require an active process of renewal and experimentation on the part of capital. This is by definition a process with unknown outcomes, and in which capital is not unified, but whereby different capitalist fractions will come to stand against each other: think for example about the big oil companies and car manufacturers on the one hand, and recycling and renewable energy industries, on the other. It is far from certain whether each and every boundary can, and will, indeed be turned into a mere barrier, and what the consequences of this will be.

Undoubtedly, capitalism has a certain capacity to develop 'greener' techniques, production processes and products. Early capitalists in the Netherlands made a profit from windmills, and they can perfectly do that again (Abramsky 2010). The real question is whether that is also possible on a macrolevel (Tanuro 2010). Is it possible for the global economy to be based on capital accumulation, and at the same time to maintain biodiversity, stop desertification and deforestation, and limit the emissions of $\mathrm{CO}_{2}$ and other harmful substances? This is a very complex question, to which it is difficult to provide exact answers. The least we can say is that it will not be easy for capitalism to turn the obstacles it is faced with into mere barriers.

In what follows, we want to shortly discuss a number of difficulties which capitalism will be confronted with in its attempt to renew itself, and which might mean that it will nevertheless be confronted with real limits or boundaries. If that is the case, the attempt to realize a passive revolution within the framework of the 'Green Economy' might be vain, and this can enlarge the space for alternative forces, gathered under the banner of 'climate justice'.

\section{Limits of Green Growth}

A first limit is that of growth, and the illusion of so-called 'green growth'. "Growth is not negotiable", Thomas Friedman $(2008,55)$ states. "To tell people they can't grow is to tell them they have to remain poor forever". Therefore, Friedman advocates green growth, as do the World Bank or the OECD. UNEP $(2011,504)$ claims that "a Green Economy grows faster than a brown economy over time, while maintaining and restoring natural capital". But this thesis, and the very notion of 'green growth' is increasingly put into question (Victor and Jackson 2012; Hoffmann 2011; Jackson 2009; Heinberg 2011).

The big challenge for advocates of green growth is to make the rate of dematerialization and decarbonization high enough to make sure that continuing economic growth corresponds with less ecological impact. As Minqi Li (2008) has shown, however, if we want to realize the most ambitious scenario which the IPCC puts forward in its 2007 report, namely 445 ppm $\mathrm{CO}_{2}$ eq [parts per million $\mathrm{CO}_{2}$ equivalent] (which, in the meantime, has been questioned by a number of scientists as being not ambitious enough (Hansen et al. 2008)), extremely strong reductions of energy and carbon intensities will be required if we still want to retain some scope for economic growth. In the period 1973-2005, the emissions intensity of the global economy diminished with $0,3 \%$, the energy intensity with $0,9 \%$ per year, while economic growth was $3 \%$ on average. Li develops a number of scenario's with much stronger reductions in emissions and energy intensity in global production. His most ambitious scenario puts 
forward combined yearly reductions of the emissions intensity by $2,7 \%$ and of energy intensity of $2 \%$. However, as he shows, even this scenario does not leave any scope for economic growth. According to Li, the global economy will still have to shrink by about $0,7 \%$ to reach the $445 \mathrm{ppm}$ objective, which is already not the most ambitious scenario imaginable.

Obviously, there is also a tension between pursuing growth on the one hand, and striving for a more just distribution of economic welfare, for example between the Global North and the Global South, on the other, as Victor and Jackson (2012) have shown. The problem is that from a social justice perspective, the Global South should be allowed to realize a certain amount of further development and economic growth, in order to satisfy basic social needs. Therefore, the reduction of $\mathrm{CO}_{2}$ intensities should proceed much faster than when no account was taken of global inequalities. This is especially so because current $\mathrm{CO}_{2}$ intensities in many southern countries are higher than the global average. "(I)t is unlikely", the authors conclude, "that reductions in $\mathrm{CO}_{2}$ emissions (...) and significant closure of the gap between rich and poor (...) are simultaneously possible without some curtailment of ambitions for economic growth" (Victor and Jackson 2012, 15).

\section{Getting prices right?}

A second problem is how to make the transition from fossil fuel capitalism to a Green Economy. More precisely, the question is whether it is possible to effectively realize such a transition in a short enough lapse of time if the chosen pathway is through the market. One example of the type of problems encountered is the question how high the price should be that is put on $\mathrm{CO}_{2}$ in order to make sharp reductions possible. As Kevin Anderson (2012) argues, " $(\mathrm{t})$ he price would almost certainly be beyond anything described as marginal (probably many €100s/ton) - hence the great 'efficiency' and 'least-cost' benefits claimed for markets would no longer apply". The point is that the needed change is so great that it cannot easily be grasped within the neoclassical paradigm of economics, which tends to focus on marginal change and incremental adjustments (Anderson 2012; Anderson and Bows 2013).

In his famous 2006 report on the cost of climate change, Nicholas Stern puts forward the climate objective of 500 to $550 \mathrm{ppm} \mathrm{CO} \mathrm{C}_{2} \mathrm{eq}$, which is much higher than what is deemed necessary by recent climate reports (e.g., Hansen et al. 2008; IPCC 2007). A stronger reduction of emissions is not possible since this would endanger the normal functioning of the market, Stern $(2006,247)$ suggests: "Digging down to emissions reductions of $60-80 \%$ or more relative to baseline will require progress in reducing emissions from industrial processes, aviation, and a number of areas where it is presently hard to envisage cost-effective approaches". Furthermore, he states that "( $p$ )aths requiring very rapid emissions cuts are unlikely to be economically viable" (Stern 2006, 203; see also Tanuro 2010).

The conclusion is clear: it seems not to be evident to realize a market-steered transition to a decarbonized economy. Unless one attenuates the climate objectives, which is what Stern appears to do in his 2006 report, as Daniel Tanuro $(2010)$ has shown. Stern $(2006,204)$ puts forward the objective of $550 \mathrm{ppm}$ as the only economically attainable goal, as "(e)xperience suggests it is difficult to secure emission cuts faster than about $1 \%$ per year except in instances of recession". Yet, according to climate scientists, the objectives will have to be much sharper, and they will have to be realized much more quickly. Scenarios of at least $2 \%$ reduction of $\mathrm{CO}_{2}$ emissions per year might be needed (Kasibhatla, Chameides, et al 2007). In more recent work, Stern (2009) recognizes that sharper reductions will be 
necessary, and puts forward the global objective of $500 \mathrm{ppm} \mathrm{CO} \mathrm{CO}_{2} \mathrm{eq}\left(450 \mathrm{ppm}\right.$ for $\left.\mathrm{CO}_{2}\right)$. However, as we have shown, climate scientists such as James Hansen (2008) argue in the meantime that even this objective is not ambitious enough, and they therefore advocate a limit of $350 \mathrm{ppm}$ for $\mathrm{CO}_{2}$.

A similar problem is observable in UNEP's Green Economy report. The latter develops two green investment scenario's: the first, G1, implies a yearly investment in greening the economy of $1 \%$ of global GNP, the second, G2, represents an investment of $2 \%$ per year. Strikingly, even the more ambitious $G 2$ scenario only succeeds in reducing the $\mathrm{CO}_{2}$ emissions by 2050 with a third compared to 2011, which equals a reduction of 4 to 7\% compared to 1990 (UNEP 2011; IBON 2011, 7). This is far below what is needed according to climate scientists (e.g. Hansen et al. 2008).

\section{The social cost of the Green Economy project}

A third obstacle is that the transition towards a green capitalism will probably also put a lot of pressure on relations between social classes. Since thirty years, the share of wages in national income is decreasing in a large part of the world. Will a greener capitalism reverse this trend, or reinforce it? Which impact will the Green Economy have on the distribution of wealth between labor and capital? An often heard argument is that greening the economy will create new jobs. Underlying is the idea that a sustainable society will possibly more strongly rely on labor-intensive activities, instead of replacing human labor by fossil-fuel driven machines. The question is what effect this can or will have on the rate of exploitation of labor. Thanks to cheap fossil-fuel based energy, capitalists have been able to massively substitute machines for labor and in this way lower production costs. The question is whether this tendency can so simply be reversed. There are good reasons to doubt whether a greener capitalism can create many jobs without at the same time putting huge pressure on wages, which means workers and poor people will carry a disproportionate burden. Under certain conditions, such as fordism, win-win situations between labor and capital seem to be possible: economic growth and increasing productivity can engender higher wages for workers along with high profits for capital. However, the downside of the fordist compromise is that it led to historically unprecedented levels of energy consumption, deepening the ecological crisis (Altvater 1993, 187). The historical exhaustion of this fordist model and tightening ecological limits make it increasingly difficult to realize such win-win situations. If economic growth can no longer be used to 'buy' social peace, struggles for redistribution will plausibly gain in importance.

According to the French economist Michel Husson (2009), a greener capitalism is in principle not impossible. But there are two conditions. First, a global institution is needed that can impose norms which radically go against the 'spontaneous' functioning of the market. And second, a carbon price has to be introduced which is so high that it will affect profitability and in all probability lead to the rapid collapse of many companies and even entire sectors. A scenario for a green capitalism therefore threatens to have to go through a period of crisis and turbulence before it finds a new equilibrium. The price that has to be put on carbon might be so high that the proper functioning of the market can be severely disturbed. Yvo de Boer, the former secretary-general of the UNFCCC, argues that the price for carbon should be set at 150 euro per ton $\mathrm{CO}_{2}$ (EurActiv 2012). This is much more than the average 7 to 8 euro which a ton of $\mathrm{CO}_{2}$ emissions cost within the European emissions trading system during the first Kyoto period. The risk is that such high carbon prices, while sensible from a climate science point of view, might be difficult for the market to absorb without heavy shocks. These shocks will not merely be economic, but especially also 
social shocks, with many people losing their jobs in a short lapse of time, and not being sure whether the new 'green' sectors will be able to offer them alternative employment. It is therefore very questionable whether it is desirable and feasible to organize the transition to a sustainable society via market mechanisms and incentives.

A final big problem, related to the difficulty of transition, is the following. According to calculations by the Carbon Tracker Initiative in 2011, only 565 gigatons of $\mathrm{CO}_{2}$ could still be emitted before 2050 if we want to stabilize the climate $\left(2^{\circ} \mathrm{C}\right.$ global warming) ${ }^{3}$ (Campanale and Leggett 2012). At the same time, the proven reserves of fossil fuels were equivalent to 2,795 gigatons of $\mathrm{CO}_{2}$ at that moment, which is about five times as much. This means there is only a limited amount of fossil fuels that can still be burnt to generate energy. In itself, this creates already the possibility for economic shocks: if the world would be serious about keeping fossil fuels in the ground, the market capitalization of major oil firms might collapse, sending shock-waves through the economic and financial system. This once again reveals the double bind we are confronted with when we stay within a market logic: either climate shocks or economic and social shocks.

\section{A tale of two myths}

Capitalism can deal creatively with these obstacles, but turning them into mere barriers will require a lot of 'inventiveness', to say the least. It will probably include a number of struggles to control natural resources, and to shift the burden of adjustment onto lower classes and the Global South. In order to break open the Green Economy discourse, and create a space for alternative discourses, it is important to pinpoint to these problems of the Green Economy both from an ecological and a social justice perspective, and repoliticize the debate on climate change.

As has been suggested previously, the Green Economy project is one possible further development of the idea of sustainable development. One of the latter's basic slogans ('People Planet Profit') is making its reappearance. UNEP, for example, explicitly dismisses the idea that there are tradeoffs between profit and planet. "Perhaps the most prevalent myth is that there is an inescapable tradeoff between environmental sustainability and economic progress", it is argued in its Green Economy report (UNEP 2011, 16). "There is now substantial evidence that the greening of economies neither inhibits wealth creation nor employment opportunities. To the contrary, many green sectors provide significant opportunities for investment, growth and jobs." Similarly, in the Rio+20 document on the Green Economy, it is stated: "We emphasize that it [the Green Economy] should contribute to eradicating poverty as well as sustained economic growth, enhancing social inclusion, improving human welfare and

\footnotetext{
${ }^{3}$ Evidently, this critical treshold is the object of an ongoing debate, which is not only scientific but also political. The target of $2^{\circ} \mathrm{C}$ warming implies that many small islands might disappear, that glaciers will significantly melt in the Himalaya, that coastal regions, for example in Bangladesh, can be threatened, and that Africa will probably face increasingly strong droughts (Bond 2012).
} 
creating opportunities for employment and decent work for all, while maintaining the healthy functioning of the Earth's ecosystems" (UN 2012). However, there are also slightly different voices: the World Bank recognizes that " $(w)$ e cannot presume that green growth is inherently inclusive. Green growth policies must be carefully designed to maximize benefits for, and minimize costs to, the poor and most vulnerable, and policies and actions with irreversible negative impacts must be avoided" (World Bank 2012, xi). Researchers sympathizing with the Green Economy project have also pointed to potential trade-offs (Barbier 2012), but stress that if well-designed, the Green Economy project can avoid or overcome them.

The recurring suggestion is therefore that tensions between people, planet and profit might occur, but are not inescapable or inevitable: with good policies and governance, a reconciliation between these goals should be possible. There are two problems with this idea. First, it tends to underestimate the extent to which hard trade-offs do exist. The most significant trade-off is the tension, or even contradiction, between limitless expansion and the finitude of the planet, which we pointed to in the previous section. Another trade-off is closely related to the issue of class. As we showed, there is a big chance that a greener capitalism can only be created by at the same time putting further pressure on wages and shifting the burden to workers and poor people.

Second, UNEP and the other international organizations favoring the Green Economy downplay the extent to which economic development, and especially social progress and sustainability are contested notions. What constitutes a reconciliation between these principles for one actor might not necessarily be perceived in the same way by another actor. By way of an example, we can point to a wellknown carbon offsetting project in Durban, South Africa (Bond and Sharife 2012). In the early 2000s, the World Bank set up a project in a landfill at Bisasar Road, which focused on the conversion of methane emissions from the landfill into electricity. At first sight, this appeared as a win-win-win situation: a significant contribution to the struggle against climate change was made by avoiding the release of methane into the atmosphere, some employment could be created for local inhabitants, and significant profits could be made from the sale of both electricity and certified emissions reduction credits. However, this example of a win-win-win situation turned out to include many 'losers'. Therefore, the landfill became a prime topic of discussion in the climate justice movement during the Durban UN Climate summit of 2011.

The landfill, the largest in Africa, had been set up during the Apartheid era, in a neighborhood mainly inhabited by black people. Many people became ill and doctors called the site a "cancer hotspot" (Bond and Sharife 2012). A popular movement demanding the closure of the site arose, and gained quite some momentum. The ANC government had pledged to close the dump, until the World Bank arrived with its carbon offsetting project. The latter gave a new lifeline to the landfill, which will probably be staying for years to come. The obvious result is that a dumpsite, a symbol of pollution and environmental destruction, can survive as it is given a green tinge. Obviously, the way the popular resistance movement estimated what constitutes social, ecological and economic advantage or progress turns out to be entirely different from how the World Bank and the UNFCCC regarded it. .

Therefore, the question which should be asked is whether the real myth is, pace UNEP, not rather the idea that profit-making, environmental protection and social progress are uncontested notions and can be reconciled without any problem. Indeed, as all myths, the storyline of the Green Economy has its effects: it not only tends to obscure real trade-offs, but it especially functions in such a way as to pull all 
the noses in the same direction, rendering certain conflicts of opinion and of interest invisible. In this sense, it inevitably functions in a depoliticizing way.

\section{Post-politics}

In general, many Green Economy discourses focus on all-round collaboration, and tend to disregard the conflicts which might spring forth from the difficult choices and trade-offs that will probably be inevitable in any process of 'greening' the economy. The realignment of a whole range of social forces through broad cooperation is underpinned by two discourses which are increasingly converging. On the one hand, there is the 'People Planet Profit' discourse mentioned above, which is older than the recent Green Economy project, but seems to revive in a new guise in the current context. On the other hand, the idea has gained force that we ought not to be divided when confronted with such a huge challenge as climate change. "Global warming is too serious for the world any longer to ignore its danger or split into opposing factions on it", Tony Blair, who during the Rio+20 conference made a speech for a "Clean Revolution" as an "expressway to the Green Economy", famously stated $(2005)$. As Swyngedouw $(2007,2010)$ aptly states: the predominant discourse is one of a common, external enemy $\left(\mathrm{CO}_{2}\right)$ which demands all-round collaboration to tackle it here and now. Given the urgency and scale of the challenge, there would be no time left for partial conflicts and discussions which divide the forces which should actually be united in this one overarching struggle against $\mathrm{CO}_{2}$ emissions (Kenis and Lievens, 2014).

A double move seems to be at work. On the one hand, the argument for all-round collaboration between governance institutions, companies and NGO's, characteristic of Green Economy discourses, is symptomatic for the broader attempt to integrate environmental antagonism into the existing institutional and economic framework, turning a matter of conflict into a motor force of economic development. On the other hand, this reconfiguration of the previous antagonism with in a new regime of economic development cannot succeed without the explicit denial of conflict, in other words, without forms of active depoliticization.

Depoliticization is the representation of social relations as if these are not characterized by political realities such as power, conflict and decision, but as if they are rational, logical, evident, grounded in nature or based on cooperation (Mouffe 2006; Lievens 2012; 2013). The recent trend towards the depoliticization of environmental discourses has been amply studied in other literatures (e.g., Swyngedouw 2007, 2010, 2013; Žižek 2007; Oosterlynck and Swyngedouw 2010; Kenis and Lievens 2014; Kenis and Mathijs 2014a; 2014b). In the framework of this paper, however, it is important to situate this resurgence of post-political environmental discourses within the ongoing movement of passive revolution, which entails a recomposition of social and political forces. This is a process in which a number of NGO's play an active role: they consciously inscribe themselves in the Green Economy project, as they perceive the latter as an opportunity to 'mainstream' their concerns. The central idea is that as a number of corporations, enterpreneurs and banks have finally discovered the ecological theme, the environmental movement no longer has to fight them, but can cooperate with them and 'help them' realize change from within. We already pointed to the example of WWF, an organization with a long track record of collaborations with multinational corporations. Many of these companies, however, engage in what is often called 'greenwashing': they present themselves as green without really transforming themselves in 
sustainable directions (e.g. Rogers 2010). BP is a typical case in point. Renaming itself 'British Petroleum' in 2001 and spending 600 million dollar to promote itself as a green company (as much as it invested in renewable energy at the time) (Worth 2010), the company remains very much focused on fossil fuels, and is involved in several projects for the exploitation of Canadian tar sands. There is very often a deep gap between theory and practice (Dale 2008), which is not always visible, and this can facilitate depoliticization.

If, on the other hand, trade-offs will inevitably arise, this depoliticization risks to mask conflicts that are real and deserve to be brought to the fore. If we want to make alternative social-ecological futures (such as imagined in the concept of 'climate justice') possible, fighting against the myth of the Green Economy project will inevitably require we fight post-politics as well. The crucial question, therefore, is how the obstacles that the Green Economy project will inevitably encounter can become the starting points for processes of repoliticization which enable alternative future possibilities.

\section{Conclusion}

In this paper, we have argued that the discursive shift that has recently taken place towards the notion of the 'Green Economy' implies a significant re-translation of the green project. The Green Economy is nothing less than a wide-scale attempt to turn ecological obstacles to capital accumulation into mere barriers that can open the door for new economic opportunities. In this sense, tackling the ecological crisis becomes the royal road for solving other problems contemporary capitalism is facing, such as the economic crisis and the crisis of legitimacy. Even though the project for a 'Green Economy' is still in its infancy and faces massive hurdles, it already triggers an important recomposition of the field of environmental politics and environmental resistance, for example, seducing numerous environmental NGO's to join its cause.

However, the breakthrough of Green Economy discourse has also led to new alternative voices. The nascent 'climate justice' movement is an important reaction to this recomposition of the environmental field. It advocates a process of profound social change beyond capitalism, supported by broad alliances of forces, including workers, peasants, women, indigenous peoples and their myriad organisations, trade unions and political forces (Bullard and Müller 2011; Bond 2012; see also Kenis and Mathijs 2014a). It centrally aims at a socially just transition to a sustainable future, based on principles of decommodification, deprivatisation, social equality, commoning and radical democracy, and thus represents an emerging opposition to the recipes of the so-called Green Economy.

\section{References}

Abramsky, K., ed. 2010. Sparking A Worldwide Energy Revolution: Social Struggles in the Transition to a Post-Petrol World. Oakland: AK Press.

Anderson, K., and Bows, A. 2012. A new paradigm for climate change. Nature Climate Change 2: 639-640. Anderson, K. 2013. Why carbon prices can't deliver the $2^{\circ} \mathrm{C}$ target, http://kevinanderson.info/blog/whycarbon-prices-cant-deliver-the-2c-target/ 
Altvater, E. 1993. The Future of the Market. An Essay on the Regulation of Money and Nature after the Collapse of 'Actually Existing Socialism'. London: Verso.

Attac. 2012. La nature n'a pas de prix. Les méprises de l'économie verte. Paris: Editions les liens qui libèrent.

Barbier, E. B. 2012. The Green Economy Post Rio+20. Science 338: 887-888.

Bernier, A. 2012. Comment la mondialisation a tué l'écologie. Les politiques environmentales piégées par le libre échange. Paris: Mille et Une Nuits.

Blair, T. 2005. Tony Blair's conference speech 2005, The Guardian, 27 September 2005.

Boltanski, L., and Chiapello, E. 2007. The New Spirit of Capitalism. London: Verso.

Bond, P. 2012. Politics of Climate Justice. Paralysis Above, Movement Below. Scottsville: University of KwaZulu-Natal Press.

Bond, P, and Sharife, K. 2012. Africa's biggest landfill site: the case of Bisasar Road. Le Monde Diplomatique - English Edition.

Buck, C. D., 2013. Post-environmentalism: an internal critique. Environmental Politics, 22 (6), 883-900.

Bullard, N. and Müller, T. 2012. Beyond the 'Green Economy': System change, not climate change? Development 55(1): 54-62.

Burkett, P. 1999. Marx and Nature. A Red and Green Perspective. New York: St. Martin's Press.

Burkett, P. 2006. Marxism and Ecological Economics. Toward a Red and Green Political Economy. Leiden: Brill.

Callinicos, A. 2010. Bonfire of illusions. The twin crises of the liberal world. Cambridge: Polity.

Campanale, M., and Leggett, J. 2012. Unburnable Carbon: Are the world's financial markets

carrying a carbon bubble? Carbon Tracker Initiative.

Gareth Dale. 2008. 'Green shift': an analysis of corporate responses to climate change. International Journal of Management Concepts and Philosophy, 3 (2): 134-155.

Energy Business Reports. 2012. GHG Emissions Credit Trading Report, http://www.energybusinessreports.com/GHG-Emissions-Credit-Trading.html.

European Commission. 2011. A Roadmap for moving to a competitive low carbon economy in 2050, http://ec.europa.eu/clima/policies/roadmap/documentation_en.htm.

ETC-Group. 2011. Who Will Control the Green Economy? ETC Group Communiqué, nr. 107.

EurActiv. 2012. Yvo de Boer: Put $€ 150$ per tonne price on carbon, http://www.euractiv.com/climateenvironment/yvo-de-boer-put-150-tonne-price-news-516383.

Foster, J.B. 2000. Marx's Ecology. Materialism and Nature. New York: Monthly Review Press.

Foster, J.B. 2002. Ecology against Capitalism. New York: Montly Review Press.

Foster, J.B., and Magdoff, F. 2009. The Great Financial Crisis: Causes and Consequences. New York: Monthly Review Press.

Foster, J.B., Clark, B. and York, R. 2010. The Ecological Rift. Capitalism's War on the Earth. New York: Monthly Review Press.

Foster, J.B. 2011. Capitalism and Environmental Catastrophe. Monthly Review, http://mrzine.monthlyreview.org/2011/foster291011.html.

Friedman, T. 2008. Hot, Flat, and Crowded: Why We Need a Green Revolution-And How It Can Renew America New York: Farrar, Straus and Giroux.

Gramsci, A. 1998. Selections from the Prison Notebooks. London: Lawrence \& Wishart. 
Green New Deal Group. 2008. A Green New Deal. Joined-up policies to solve the triple crunch of the credit crisis, climate change and high oil prices, http://greennewdeal.eu/index.php?id=51.

Hansen, J., Sato, M., Pushker, K., Beerling, D., Berner, R., Masson-Delmotte, V., Pagani, M., Raymo, M., Royer, D.L., and Zachos, J.C. 2008. Target Atmospheric $\mathrm{CO}_{2}$ : Where should Humanity Aim? Open Atmospheric Science Journal 2: 217-231.

Heinberg, R. 2011. The End of Growth. Adapting to our New Economic Reality. Forest Row: Clairview.

Hoffmann, U. 2011. Some Reflections on Climate Change, Green Growth Illusions and Development Space. UNCTAD Discussion Papers.

Husson, M. 2009. Un capitalisme vert est-il possible? Contretemps 1.

IBON. 2011. Green Economy: Gain or Pain for the Earth's Poor? Policy Brief November 2011.

Jackson, T. 2005. Motivating sustainable consumption. A review of evidence on consumer behaviour and behavioural change. Surrey: SDRN.

Jackson, T. 2009. Prosperity without Growth. Economics for a Finite Planet. London: Earthscan.

Jacobs, M. 2013. Green Growth: Economic Theory and Political Discourse. In Handbook of Global Climate and Environmental Policy, edited by R. Falkner. Oxford: Blackwell.

Jones, V. 2008. The Green Collar Economy: How One Solution Can Fix Our Two Biggest Problems. New York: HarperOne.

Joshua, I. 2009. La grande crise du XXIe siècle. Une analyse marxiste. Paris: La Découverte.

Kenis, A. and Lievens, M. 2014. Searching for the Political in Environmental Politics. Environmental Politics, art.nr. 10.1080/09644016.2013.870067..

Kenis, A., and Mathijs, E. 2012. Beyond individual behaviour change: the role of power, knowledge and strategy in tackling climate change. Environmental Education Research, 18 (1): 45-65.

Kenis, A. and Mathijs, E. 2014a. Climate change and post-politics: Repoliticising the present by imagining the future? Geoforum, 52, 148-156.

Kenis, A. and Mathijs, E. 2014b. (De)politicising the local: The case of the Transition Towns movement in Flanders (Belgium). Journal of Rural Studies, 34, 172-183.

Klitgaard, K. 2013. Heterodox Political Economy and the Degrowth Perspective. Sustainability 5: 276-297. Kovel, J. 2007. The Enemy of Nature. The End of Capitalism or the End of the World? London: Zed Books.

Laclau, E., and Mouffe, C. 2001. Hegemony and Socialist Strategy : towards a Radical Democratic Politics London: Verso.

Li, M. 2008. Climate Change, Limits to Growth, and the Imperative for Socialism. Monthly Review 60 (3).

Lievens, M. 2012. Ideology Critique and the Political. Towards a Schmittian Perspective on Ideology. Contemporary Political Theory 11(4): 381-396.

Lievens, M. 2013. Carl Schmitt's Metapolitics. Constellations 20(1): 121-137.

Marshall, C. 2010. Can Stored Carbon Dioxide Leak? Scientific American, 28 June 2010.

Marx, K. 1973. Grundrisse. London: Penguin Books.

McCormack, A. 2012. Mission Growth. Financial Times, June 6, 2012.

Mol, A. P. J. and Spaargaren, G., 2000. Ecological modernization theory in debate: a review. Environmental Politics, 9(1): 17-49.

Morris, W. $\quad$ W86. A Dream of John Ball, http://www.marxists.org/archive/morris/works/1886/johnball/johnball.htm.

Mouffe, C. 1979. Gramsci and Marxist Theory. London: Routledge \& Kegan Paul. 
Mouffe, C. 2006. On the Political. London: Routledge.

Mueller, T., and Bullard, N. 2011. Beyond the 'Green Economy': System Change, Not Climate Change? Global Movements for Climate Justice in a Fracturing World. UNRISD Conference. Geneva.

Mueller, T., and Passadakis, A. 2010. Another Capitalism is Possible? From World Economic Crisis to Green Capitalism. In Sparking a Worldwide Energy Revolution. Social Struggles in the Transition to a PostPetrol World, edited by K. Abramsky. Oakland: AK Press.

Negri, A., and Hardt, M. 2000. Empire. Cambridge: Harvard University Press.

Negri, A. and Hardt, M. 2003. Labor of Dionysus. A Critique of the State-form. Minneapolis: University of Minneapolis Press.

OECD. 2010. Interim Report of the Green Growth Strategy. Implementing our Commitment for a Sustainable Future, http://www.oecd.org/greengrowth/45312720.pdf.

Oosterlynck, S., and Swyngedouw, E. 2010. Noise reduction: The post-political quandary of night flights at Brussels airport. Environment \& Planning A 42 (7): 1577-1594.

Prasad, K., Chameides, W. et al. 2007. G8 Leadership is Critical to Curbing Energy-Related $\mathrm{CO}_{2} \mathrm{Emissions.}$ Nicholas Institute for Environmental Policy Solutions, Duke University.

Rockström, J., et al. 2009. Planetary boundaries: exploring the safe operating space for humanity. Ecology and Society 14(2): 32.

Rogers, H. 2010. Green Gone Wrong. How Our Economy Is Undermining the Environmental Revolution. London: Verso.

Runnalls, D. 2011. Environment and Economy: Joined at the Hip or just Strange Bedfellows? S.A.P.I.EN.S 4 (2).

Shear, B. 2010. The Green Economy: Grounds for a New Revolutionary Imaginary? Rethinking Marxism 22 (2): 203-209.

Smith, N. 2006. Nature as Accumulation Strategy. In Socialist Register 2007. Coming to Terms with Nature, edited by L. Panitch and C. Leys. London: The Merlin Press.

Spaargaren, G. and Mol, A., P. J., 1992. Sociology, environment and modernity: ecological modernization as a theory of social change. Society and Natural Resources, 5(5): 323-345.

Stern, $\quad$ N. 2006. The Economics of Climate http://webarchive.nationalarchives.gov.uk/+/http://www.hmtreasury.gov.uk/sternreview_index.htm.

Stern, N. 2009. A Blueprint for a Safer Planet. London: The Bodley Head.

Stewart, H. and Elliott, L. 2013. Nicholas Stern: 'I got it wrong on climate change - it's far, far worse'. The Guardian (26 January 2013).

Swyngedouw, E. 2007. Impossible "Sustainability" and the Postpolitical Condition. In The Sustainable Development Paradox, edited by R. J. Krueger and D. Gibbs. London: The Guilford Press.

Swyngedouw, E. 2010. Apocalypse Forever? Theory, Culture \& Society 27: 213-232.

Swyngedouw, E. 2013. The Non-political Politics of Climate Change. ACME. An International E-Journal for Critical Geographies 12(1): 1-8.

Tanuro, D. 2010. L'impossible capitalisme vert. Paris: La Découverte.

TNI. 2008. Climate justice groups warn of false solutions to climate change at the CBD, http://www.tni.org/archives/act/18315.

Tronti, M. 1977. Ouvriers et Capital. Paris: C. Bourgois. 
UN. 2012. The Future We Want: Rio+20 Outcome Document. Rio de Janeiro.

UNEP. 2008. Green Jobs: Towards Decent Jobs in a Sustainable, Low-Carbon World, http://www.unep.org/publications/contents/pub_details_search.asp?ID=4002.

UNEP. 2011. Towards a Green Economy: Pathways to Sustainable Development and Poverty Eradication, http://www.unep.org/greeneconomy/Portals/88/documents/ger/GER_synthesis_en.pdf.

Victor, P. A., and Jackson, T. 2012. A Commentary on UNEP's Green Economy Scenarios. Ecological Economics 77: 11-15.

World Bank. 2012. Inclusive Green Growth. The Pathway to Sustainable Development. Washington: International Bank for Reconstruction and Development / International Development Association or The World Bank.

Worldwatch Institute. 2010. State of the World. Transforming Cultures: From Consumerism to Sustainability. New York: Norton.

Worth, J. (2010). Taking on Tarmageddon. The New Internationalist, 431: 4-7.

Žižek, S. 2007. Censorship Today: Violence, or Ecology as the New Opium for the Masses, http://www.lacan.com/zizecology1.htm. 